\title{
Relationship between photosynthetic pigments and corn production under nitrogen sources ${ }^{1}$
}

\author{
Ezequiel Zibetti Fornari², Lucas Gaviraghi², Claudir José Basso², \\ Marcos Vinícius Marques Pinheiro ${ }^{3}$, André Luis Vian ${ }^{4}$, Antônio Luis Santi
}

\section{ABSTRACT}

Nitrogen $(\mathrm{N})$ is a dynamic element in the soil, so new nitrogen fertilization alternatives are required as a way of maximizing its efficiency. Besides, vegetation sensors are a way to assess and manage the nutritional demands of plants. This study aimed to evaluate the effect of nitrogen sources on photosynthetic pigments and their correlation with corn grain yield and dry biomass. The experiment was carried out in a randomized block design with nitrogen sources (mineral, organic and biological). Contents of chlorophyll $a, b$ and total, as well as carotenoids, were evaluated. The chlorophyll indices evaluated by both methods were positively correlated with each other and with the grain yield per plant. Nitrogen fertilization $100 \%$ mineral was superior, when compared to the other treatments, with increments of up to $44 \%$. There was a positive relationship between the methods of determining and estimating the chlorophyll contents. The grain yield per plant showed the highest values when using the $100 \%$ mineral fertilizer source, with increments above $10 \%$, in relation to the other sources, spending US\$ 89.77 on fertilizer and earning over US\$ 538.60 on grain yield. There was a positive correlation between the photosynthetic pigments obtained by both methods and grain yield per plant. Both methods are recommended for the evaluation of chlorophyll concentrations.

KEYWORDS: Azospirillum brasilense, nitrogen fertilization, chlorophyll, poultry litter.

\section{INTRODUCTION}

Nitrogen $(\mathrm{N})$ presents a complex dynamic, so it is difficult to recommend it, regarding the application and source to be used with a greater efficiency (Martínez et al. 2017).

\section{RESUMO}

Relação entre pigmentos fotossintéticos e produção de milho sob fontes de nitrogênio

O nitrogênio (N) é um elemento dinâmico no solo. Dessa forma, novas alternativas de fertilização nitrogenada são demandadas, como forma de maximizar a sua eficiência. Aliado a isso, os sensores de vegetação surgem como forma de avaliar e manejar as demandas nutricionais das plantas. Objetivou-se avaliar o efeito de fontes de nitrogênio nos pigmentos fotossintéticos e sua correlação com o rendimento de grãos e biomassa seca em milho. O experimento foi conduzido em blocos casualizados com fontes de nitrogênio (mineral, orgânica e biológica). Avaliaram-se os teores de clorofila $a, b$ e total, bem como de carotenoides. Os índices de clorofila avaliados por ambos os métodos se correlacionaram positivamente entre si e com o rendimento de grãos por planta. A adubação nitrogenada $100 \%$ mineral foi superior, quando comparada com os demais tratamentos, com incrementos de até $44 \%$. Verificou-se relação positiva entre os métodos de determinação e a estimativa dos teores de clorofila. O rendimento de grãos por planta apresentou os maiores valores quando se utilizou a fonte de adubação $100 \%$ mineral, apresentando incrementos acima de $10 \%$, em relação às demais fontes, com gasto de US\$ 89.77 com o fertilizante e ganho acima de US\$ 538.60 para o rendimento de grãos. Verificou-se correlação positiva entre os pigmentos fotossintetizantes avaliados por ambos os métodos e o rendimento de grãos por planta. Recomendam-se ambos os métodos para a avaliação das concentrações de clorofila.

PALAVRAS-CHAVE: Azospirillum brasilense, adubação nitrogenada, clorofila, cama de aves.

Harty et al. (2017) demonstrated a great variation in the use of $\mathrm{N}$ by plants, ranging 5-78 \%, depending on dose, source and interaction with the environment. Besides, in the same study, it was possible to verify a variation of $62-75 \%$ of absorption among the $\mathrm{N}$ sources, in six study sites,

${ }^{1}$ Received: May 29, 2020. Accepted: Aug. 17, 2020. Published: Oct. 21, 2020. DOI: 10.1590/1983-40632020v5063661. ${ }^{2}$ Universidade Federal de Santa Maria, Departamento de Ciências Agronômicas e Ambientais, Frederico Westphalen, RS, Brasil. E-mail/ORCID: ezequiel.fornari@yahoo.com.br/0000-0002-0513-2120, lucasgaviraghi@hotmail.com/0000-0001-8264-9038, claudirbasso@gmail.com/0000-0002-3013-5702,santi_pratica@yahoo.com.br/0000-0002-4773-4912.

${ }^{3}$ Universidade Estadual do Maranhão, São Luís, MA, Brasil. E-mail/ORCID: macvini@gmail.com/0000-0002-5028-7818.

${ }^{4}$ Universidade Federal do Rio Grande do Sul, Departamento de Plantas de Lavoura, Porto Alegre, RS, Brasil. E-mail/ORCID: andre.vian@ufrgs.br/0000-0002-9781-1533. 
and, in the case of urea, there was a variation of $57-100 \%$ of $\mathrm{N}$ in different locations. Regarding the application time, the lowest $\mathrm{N}$ absorption was observed in early spring (37\%) and late summer (64\%), and the highest values were identified in late spring, early summer and development $(95,86$ and $78 \%$, respectively).

Replacing mineral sources with organic ones is one of the ways to increase the efficiency in the use of N. Mineral sources are more susceptible to N loss than organic fertilization, due to the mineralization speed (Martínez et al. 2017). Organic fertilization obtained from poultry litter has been used as an alternative to replace mineral fertilization, as a way to promote corn production, and it may increase up to $300 \mathrm{~kg} \mathrm{ha}^{-1}$ of grains for every $1,000 \mathrm{~kg} \mathrm{ha}^{-1}$ applied (Santos et al. 2014).

Another strategy of supplying $\mathrm{N}$ to crops is the use of diazotrophic bacteria, such as Azospirillum brasilense. Kappes et al. (2013) verified an increase of $10 \%$ in the yield of corn crops and slight increases of $3.8,3.0,6.3$ and $2.8 \%$ in length, prolificacy, plant height and ear insertion height, respectively. According to Quadros et al. (2014), inoculation favors the performance of corn hybrids in a different way, as they verified increases in the relative chlorophyll content, shoot dry matter yield, 1,000-grain weight and plant height, when comparing plants with and without inoculation.

High levels of $\mathrm{N}$ in the leaf tissue influence the levels of chlorophylls (Hurtado et al. 2011). That is explained by the fact that $50-70 \%$ of the $\mathrm{N}$ present in the leaves are a constituent of chlorophyll $a, b$ and carotenoids linked to chloroplasts, providing raw material for the Calvin cycle (Latsague et al. 2014, Sánchez et al. 2018). Chlorophylls and carotenoids are photosynthetic pigments capable of absorbing light, transmitting energy to the photochemical and biochemical phases of photosynthesis and accumulating chemical energy that is stored as sugar.

Therefore, levels of photosynthetic pigments are presented as a parameter to understand crop yield. Fertilization with 150 and $300 \mathrm{~kg} \mathrm{ha}^{1}$ of $\mathrm{N}$ increased the chlorophyll content in 30.5 and $33.3 \%$, respectively, in relation to the control (Ya-weil et al. 2019). Sensors such as chlorophyll meters are used to promote practicality in field evaluations, diagnosing the $\mathrm{N}$ supply during the crop cycle.

Thus, this study aimed to evaluate nitrogen sources and their effects on photosynthetic pigments and their correlation with corn grain yield and dry biomass.

\section{MATERIAL AND METHODS}

The experiment was carried out at the experimental area of the Universidade Federal de Santa Maria, located in the middle upper Uruguay region $\left(27^{\circ} 23^{\prime} 51^{\prime}\right.$ 'S, 53 $35^{\circ} 19^{\prime}$ 'W and altitude of $490 \mathrm{~m}$ ), in Frederico Westphalen, Rio Grande do Sul state, Brazil, in the 2017/2018 crop year. According to the Köppen climate classification, the region is classified as $\mathrm{Cfa}$, with a humid subtropical climate, average precipitation of $1,881 \mathrm{~mm}$ and average air temperature of $19.1{ }^{\circ} \mathrm{C}$ (Alvares et al. 2013).

The experimental area has a deep, well-drained and clayey soil, classified as a typical Dystrophic Red Latosol (Embrapa 2018), with the following characteristics: clay content: $64 \% ; \mathrm{pH}\left(\mathrm{H}_{2} \mathrm{O}\right)$ : 5.9; P: $3.2 \mathrm{mg} \mathrm{dm}^{-3}\left(\mathrm{Mehlich}^{-1}\right)$; K: $214.5 \mathrm{mg} \mathrm{dm}^{-3} ; \mathrm{Ca}^{2+}$ : $6.2 \mathrm{cmol}_{\mathrm{c}} \mathrm{dm}^{-3}$ CEC pH 7.0: $16.7 \mathrm{cmol}_{\mathrm{c}} \mathrm{dm}^{-3}: \mathrm{Mg}^{2+}$ : $3.4 \mathrm{cmol}_{\mathrm{c}} \mathrm{dm}^{-3}$; and $3.1 \%$ of organic matter. The recommendations for phosphorus and potassium were carried out according to SBCS (2016). At sowing, corrective phosphorus fertilization was performed in the sowing furrow with $215 \mathrm{~kg} \mathrm{ha}^{-1}$ of $\mathrm{P}_{2} \mathrm{O}_{5}$, with triple superphosphate as source.

The corn sowing was carried out on ryegrass (Lolium multiflorum) crop residues, using a DEKALB 290 VTPRO3 hybrid of early cycle, with the seeds being manually laid to the ground with spacing of $0.30 \mathrm{~m}$ and depth of $0.03 \mathrm{~m}$, for a population of 74,000 plants ha ${ }^{-1}$.

The experiment was carried out in a randomized block design, with six treatments and four replicates, applying fertilization with mineral $\mathrm{N}$, organic fertilization with poultry litter and inoculation with Azospirillum brasilense (Table 1).

The $\mathrm{N}$ was supplied at a dose of $180 \mathrm{~kg} \mathrm{ha}^{-1}$ to achieve the grain yield of $11,000 \mathrm{~kg} \mathrm{ha}^{-1}$ (SBCS 2016). Each experimental plot consisted of six cultivation lines spaced $0.45 \mathrm{~m}$ and $5.00 \mathrm{~m}$ long, with $13.5 \mathrm{~m}^{2}$ of total area and $7.2 \mathrm{~m}^{2}$ of useful area.

Treatments with inoculation (T2, T4 and T5) were applied at the sowing day, with $4 \mathrm{~mL} \mathrm{~kg}^{-1}$ of seeds with Azototal ${ }^{\mathrm{TM}}$ (Azospirillum brasilense), registered in the Brazilian Ministry of Agriculture, Livestock and Food Supply with strains AbV5 and AbV6, in a concentration of $2.0 \times 108 \mathrm{CFU} \mathrm{mL}^{-1}$, 
Table 1. Treatments with nitrogen doses and sources.

\begin{tabular}{lcl}
\hline \multicolumn{1}{c}{ Treatments } & N dose $\left(\mathrm{kg} \mathrm{ha}^{-1}\right)$ & N source \\
\hline T1 - without N & 0 & - \\
T2 - Biological & 0 & Azospirillum brasilense \\
T3 - Mineral & 180 & Urea \\
T4 - Mineral + biological & 90 & Urea + Azospirillum brasilense \\
T5 - Mineral + organic + biological & $90+90$ & Urea + poultry litter + Azospirillum brasilense \\
T6 - Mineral + organic & $90+90$ & Urea + poultry litter \\
\hline
\end{tabular}

with the addition of $4 \mathrm{~mL}$ of distilled water for homogenization of the inoculant on the seeds.

A total of $6,545 \mathrm{~kg} \mathrm{ha}^{-1}$ of poultry litter was applied (T5 and T6). It presented a concentration of $2.75 \%$ of $\mathrm{N}$, considering a $50 \%$ efficiency of $\mathrm{N}$ release, with $90 \mathrm{~kg} \mathrm{ha}^{-1}$ of $\mathrm{N}$ released for the crop. The dose of $30 \mathrm{~kg} \mathrm{ha}^{-1}$ of mineral $\mathrm{N}$ was applied at sowing (urea - T3, T4, T5 and T6). Afterwards, the remaining portion of the $\mathrm{N}$ dose was divided into two cover applications, being $50 \%$ at $\mathrm{V} 4$ and $50 \%$ at V8 (SBCS 2016).

According to Hurtado et al. (2010), the phenological stage R3 presents a high correlation with grain yield. Therefore, this stage was defined for the evaluation of chlorophyll $a$ (Gcla), chlorophyll $b$ (Gclb) and total chlorophyll (Gclt) with the use of a portable chlorophyll meter CLOROFILOG ${ }^{\mathrm{TM}}$, with data expressed by the dimensionless Falker chlorophyll index. The chlorophyll meter reads the transmittance of three wavelengths $(\lambda)-635$ and $660 \mathrm{~nm}$ (red) and $880 \mathrm{~nm}$ (infrared) - to indicate the chlorophyll index and estimate the presence of chlorophyll types $a, b$ and total. The readings were taken in each portion of the leaf blade (lower, central and upper), on the first opposite leaf below the ear insert (Hurtado et al. 2011).

At the same time, five leaf discs with $5 \mathrm{~mm}$ in diameter were collected to extract the chlorophyll $a, b$ and total, as well as carotenoids (Clad, Clbd, Cltd and Car, respectively). Then, the disks were submerged in $5 \mathrm{~mL}$ of DMSO solution (saturated with calcium carbonate) for 48 hours (Santos et al. 2008). After the incubation period, the laboratory determined the absorbance of the samples in a quartz cuvette with $10 \mathrm{~mm}$ optical path, in a double-beam spectrophotometer (BEL PHOTONICS 1105). The wavelengths for calculating the chlorophyll $a$ and $b$ and carotenoid concentrations were 645,665 and $480 \mathrm{~nm}$, respectively (Wellburn 1994). The total chlorophyll and carotenoid values determined the ratio between the total chlorophyll and carotenoids (Cltd/Car).

The readings in both methods were performed on five plants identified in the useful area of the experimental unit, performed on the first opposite leaf below the ear insert (Hurtado et al. 2011). First, the reading was performed with the CLOROFILOG ${ }^{\mathrm{TM}}$, and then the leaf was collected for determination in the laboratory.

For the dry mass evaluations, five whole plants were collected at the R1 phenological stage and taken to a forced air circulation oven at $65^{\circ} \mathrm{C}$, for later determination of the total dry mass. The grain yield per plant was determined in the same plants, collecting the leaf for the determination of chlorophyll in the field, the grain mass was corrected to $13 \%$ of humidity and, subsequently, the average grain yield per plant was calculated.

During the 2017/2018 crop year, there was an accumulated rainfall of $1,217.4 \mathrm{~mm}$ between October and March. However, due to the irregularity in the precipitation distribution, it was necessary to perform a sprinkler irrigation, applying a $20-\mathrm{mm}$ blade in December (stage V7) and in January (V11) (Figure 1). Regarding the temperatures, there were variations in temperature within the optimal range of the crop.

Data were submitted to analysis of variance and the treatments and methods were compared using the Scott-Knott test at $5 \%$ of probability and, subsequently, the variables subjected to the Pearson's linear correlation analysis and the regression test. The analyzes were performed by the Genes statistical software (Cruz 2013).

\section{RESULTS AND DISCUSSION}

Concerning the analysis of variance, the results were significant $(\mathrm{p}<0.05)$ for chlorophyll $a$ (Clad), chlorophyll $b$ (Clbd), total chlorophyll 


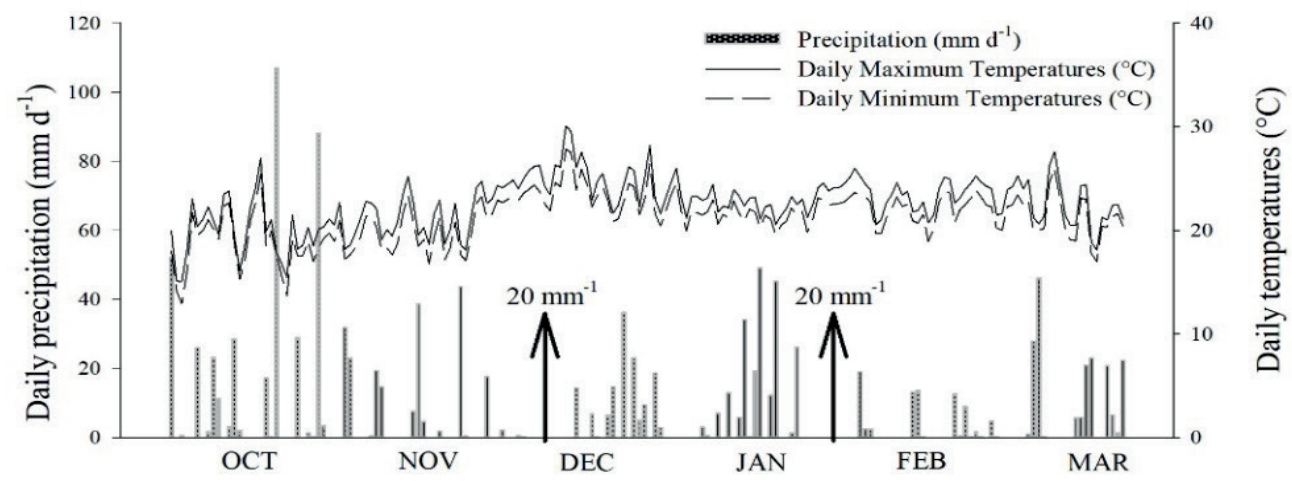

Figure 1. Daily maximum and minimum temperatures, daily precipitation and irrigation throughout the experiment.

(Cltd) and carotenoids (Car) by the DMSO extraction method; and, by the field determination, there was significance for chlorophyll $a$ (Gcla), chlorophyll $b$ (Gclb), total chlorophyll (Gclt) and grain yield. However, there was no significance $(\mathrm{p}<0.05)$ for the variables Cltd/Car and dry mass. The method of extracting chlorophylls via DMSO, for chlorophyll $a$ (Clad) and total chlorophyll (Cltd) or the chlorophyll $a$ (Gcla) and total (Gclt) index, via CLOROFILOG ${ }^{\mathrm{TM}}$, were efficient in separating treatments with different sources of $\mathrm{N}$ in three groups. The nitrogen fertilization $100 \%$ mineral (T3) was superior, in relation to the other treatments. The treatments without $\mathrm{N}$ (T1) and the one with biological fertilization (T2) presented the lowest concentrations of chlorophyll contents (Figures 2A, 2B and 2C). For the treatments with mineral, organic and biological fertilization (A. brasilense), isolated or associated (T4, T5 and T6), there was no significant difference for the analyzed variables (Figures 2 e 3 ).

Chlorophyll $b$ showed a significant difference between the treatments, when analyzed by the two methods (Figure 2B). For Gclb, the treatment T3 showed the highest values, differing from the association of $\mathrm{N}$ sources, in relation to the other treatments. However, for Clbd, T3 did not differ from the treatments T5 and T6 (Figure 2B).

For the carotenoids extracted in the laboratory, a similar variation of the variables Gclt, Cltd, Clbd, Gclb, Clad and Gcla was observed. T3 showed the highest value, when compared to the other treatments (Figure 2D). For the relationship between total chlorophyll and carotenoids (Cltd/Car), there was no significant difference, demonstrating that there was no change in the proportion between chlorophylls and carotenoids (Figure 2D).
The variation of photosynthetic pigments, with or without the use of inoculation with $A$. brasilense, mainly the treatments T3, T4, T5 and T6, is explained by the physiology of the bacteria (Figure 2). The biological fixation by diazotrophic bacteria (e.g., A. brasilense) may have its efficiency reduced or inhibited in the presence of nitrogenous compounds such as ammonium, which inhibits the activity of the nitrogenase enzyme, which has the function of converting the atmospheric nitrogen $\left(\mathrm{N}_{2}\right)$ in compounds assimilable by the plant, directly impacting the plant's physiology, since $\mathrm{N}$ is an essential constituent of chloroplasts and chlorophyll (Prakamhang et al. 2009). According to the authors, the regulation of the nitrogenase enzyme is necessary due to the enormous energy expenditure in the $\mathrm{N}_{2}$ reduction process, being necessary around 28 moles of ATP to synthesize one mole of ammonia.

The replacement of part of the mineral fertilization by organic fertilization promoted a decrease in the levels of photosynthetic pigments (Figure 2). This fact is justified by the reduction in the availability of mineral $\mathrm{N}$ to the plant and the lack of synchronism between the availability of $\mathrm{N}$ and plant demand due to the process of mineralization of $\mathrm{N}$, associated with the division of $\mathrm{N}$ doses. According to Santos et al. (2014), gains in grain yield were identified with the use of organic fertilizer in the crop before corn.

For the variable grain yield per plant, there was a significant difference, with the treatment T3 showing the highest grain yield per plant. For the variable dry mass yield per plant, there was no significant difference (Figure 3).

The replacement of half of the mineral fertilization by the addition of poultry litter decreased 

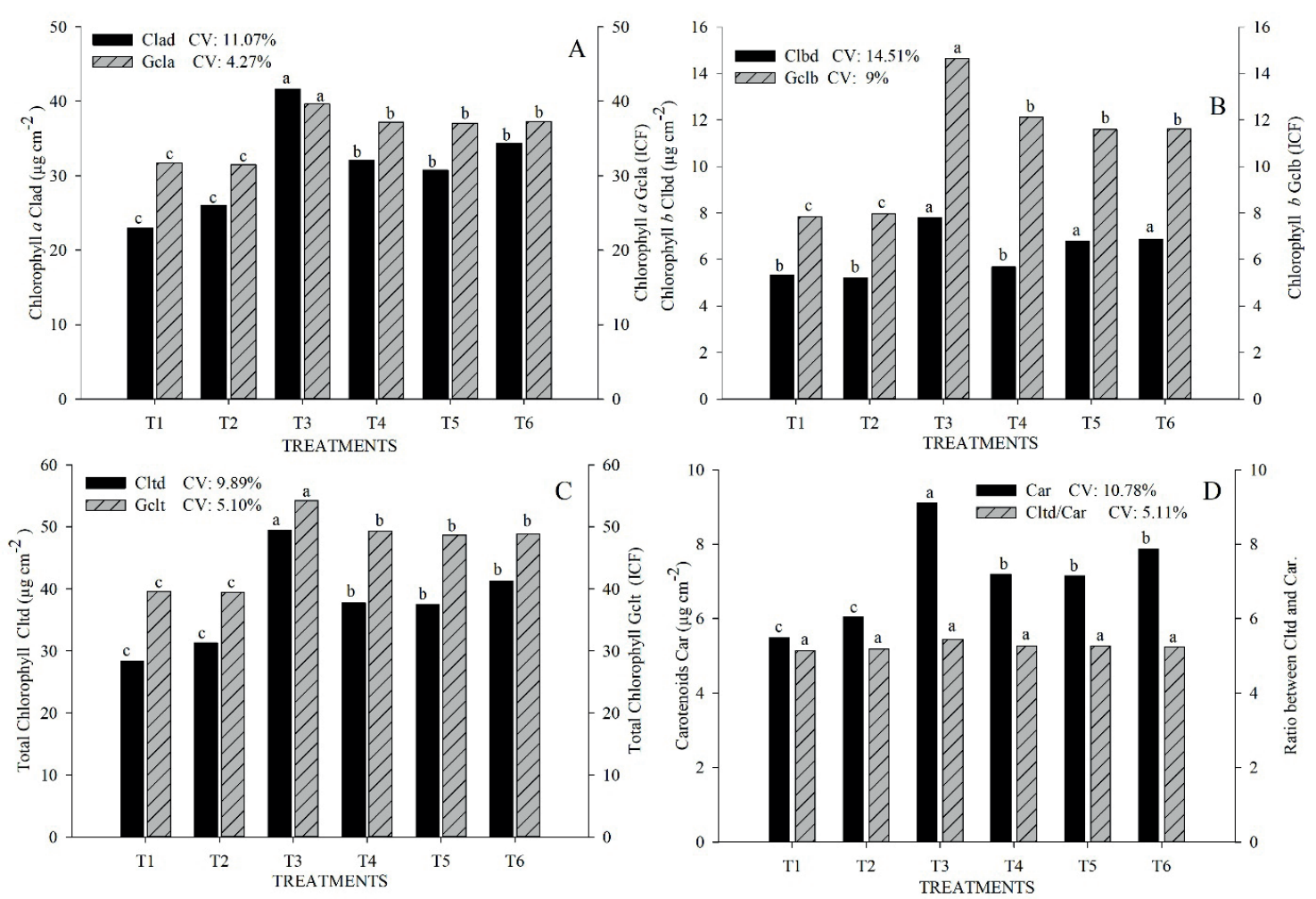

Figure 2. Chlorophyll $a$ by extraction method (Clad) and field determination (Gcla) (A); Chlorophyll $b$ by extraction method (Clbd) and field determination (Gclb) (B); total chlorophyll by extraction method (Cltd) and field determination (Gclt) (C); carotenoids (Car) and ratio between total chlorophyll and carotenoids (Cltd/Car) (D). T1: without N; T2: inoculation with Azospirillum brasilense; T3: $180 \mathrm{~kg} \mathrm{ha}{ }^{1}$ of N via urea; T4: $90 \mathrm{~kg} \mathrm{ha}^{-1}$ of N via urea and inoculation with Azospirillum brasilense; $\mathrm{T} 5: 90 \mathrm{~kg} \mathrm{ha}^{-1}$ of $\mathrm{N}$ via urea, with $90 \mathrm{~kg} \mathrm{ha}^{-1}$ of $\mathrm{N}$ via poultry litter and inoculation with Azospirillum brasilense; T6: $90 \mathrm{~kg} \mathrm{ha}^{-1}$ of $\mathrm{N}$ via urea, with $90 \mathrm{~kg} \mathrm{ha}^{-1}$ of $\mathrm{N}$ via poultry litter. Means followed by different letters differ from each other by the Scott-Knott test at $5 \%$ of probability. CV: coefficient of variation.

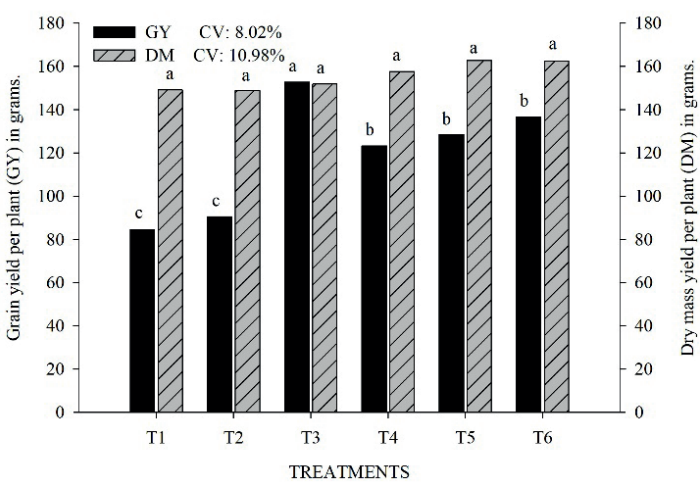

Figure 3. Grain yield per plant (GY) and dry mass per plant (DM), as a function of nitrogen sources. T1: without N; T2: inoculation with Azospirillum brasilense; T3: $180 \mathrm{~kg} \mathrm{ha}^{-1}$ of $\mathrm{N}$ via urea; $\mathrm{T} 4: 90 \mathrm{~kg} \mathrm{ha}^{-1}$ of $\mathrm{N}$ via urea and inoculation with Azospirillum brasilense; T5: $90 \mathrm{~kg} \mathrm{ha}^{-1}$ of $\mathrm{N}$ via urea, with $90 \mathrm{~kg} \mathrm{ha}^{-1}$ of $\mathrm{N}$ via poultry litter and inoculation with Azospirillum brasilense; T6: $90 \mathrm{~kg} \mathrm{ha}^{-1}$ of $\mathrm{N}$ via urea, with $90 \mathrm{~kg} \mathrm{ha}^{-1}$ of $\mathrm{N}$ via poultry litter. Means followed by different letters differ from each other by the Scott-Knott test at $5 \%$ of probability. CV: coefficient of variation. the grain yield per plant, in relation to mineral fertilization. This fact is explained by the change of the photosynthetic pigments. This behavior corroborates the results observed by Santos et al. (2014), who obtained an increase in corn grain yield when using doses above $7,500 \mathrm{~kg} \mathrm{ha}^{-1}$ of poultry litter, when studying the application of poultry litter in oat/corn succession. However, the excess of organic fertilization has a potential for environmental contamination by leaching of nitrate and release of greenhouse gases with $\mathrm{NH}_{3}, \mathrm{CO}_{2}, \mathrm{CH}_{4}, \mathrm{~N}_{2} \mathrm{O}$ and $\mathrm{H}_{2} \mathrm{~S}$ (Minogue et al. 2012).

However, the application of organic fertilizers may positively affect the soil quality, increasing the stock of organic carbon over successive agricultural crops. In high doses, these fertilizers may partially or totally replace mineral fertilizers (Martínez et al. 2017). According to Ferro et al. (2018), fertilization with poultry litter improves the initial development of wheat plants, due to the gradual release of $\mathrm{N}$ to the plants. 
The inoculation with $A$. brasilense did not influence the grain yield per plant, a result that corroborates Dartora et al. (2013). This is due to the high availability of $\mathrm{N}$ to the plants, affecting the association of the bacteria with the plant and nullifying the benefits of inoculation (Sangoi et al. 2015, Portugal et al. 2017). The variation for grain yield may be justified by the variation in the levels of photosynthetic pigments. However, it is necessary to remember that the grain yield (GY) obtained even without nitrogen fertilization is the result of a series of factors that promoted the development of the crop, such as organic matter content, hybrid with high productive potential used, favorable water and climatic conditions (Figure 1). These results corroborate Lana et al. (2012), studying the association of $A$. brasilense with nitrogen fertilization in corn (AG 6018 YG), in the no-tillage system, in an Eutrophic Oxisol, in two areas in Cascavel, Paraná state, Brazil,with fertility similar to that in the present study.

By reducing the nitrogen fertilizer to half of the mineral $\mathrm{N}$ and adding $A$. brasilense, there is a $19.24 \%$ reduction in the grain yield per plant. These data are similar to those found by Sangoi et al. (2015), who added $A$. brasilense at medium and high nitrogen fertilization levels in the corn crop, diverging from the results found by Dartora et al. (2013), who observed the maximum yield of corn biomass using inoculation with A. brasilense. Such results in the literature are different because the effectiveness of inoculation may vary depending on the genotype, strain used (specificity) and edaphoclimatic conditions (Quadros et al. 2014).

There was a positive correlation $(\mathrm{p}<0.01)$ between GY x Clad, Car, Cltd, Gcla, Gclb, Gclt, and a positive correlation $(\mathrm{p}<0.05)$ between $\mathrm{GY}$ x Clbd,
Cltd/Car, demonstrating that photosynthetic pigments have a high relationship with GY, and can be used to correlate with GY. The carotenoids levels presented a high correlation with the chlorophylls levels and indexes (Table 2).

The chlorophylls levels expressed by the methods extraction by DMSO (laboratory) and CLOROFILOG $^{\text {TM }}$ (field) showed a high correlation. The similarity between the analyzed variables is justified by the high significance levels of the correlation coefficients, corroborating Sánchez et al. (2018), who reported a high correlation between chlorophyll $a, b$ and total and carotenoids, under doses of nitrogen, phosphorus and potassium. The correlation coefficient between the chlorophylls extracted by the DSMO method and estimated in the field allows to infer that the CLOROFILOG ${ }^{\mathrm{TM}}$ can replace the destructive method DMSO to estimate the chlorophyll content more quickly, with a lower cost and without damages (Schlichting et al. 2015).

When observing the data for the chlorophylls $a, b$ and total, there is a linear adjustment for the three variables (Figure 4). As already discussed and presented throughout the study, it seems that the field method presents an estimate of chlorophyll concentrations and not a determination, when compared to the destructive laboratory method.

This evaluation indicates a higher concentration of chlorophylls using the CLOROFILOG ${ }^{\mathrm{TM}}$, when compared to the DMSO method. This is because the CLOROFILOG $^{\text {TM }}$ makes specific estimates on the leaf. However, even with this variation, it is possible to verify the same tendency among the methods used to quantify the chlorophyll contents. Considering these observations, it is recommended to use the

Table 2. Pearson's linear correlation matrix between chlorophyll estimation methods and grain yield.

\begin{tabular}{llcccccccc}
\hline & GY & Clad & Clbd & Car & Cltd & Cltd/Car & Gcla & Gclb & Gclt \\
\hline GY & 1 & & & & & & & & \\
Clad & $0.96^{* *}$ & 1 & & & & & & & \\
Clbd & $0.92^{*}$ & $0.90^{*}$ & 1 & & & & & & \\
Car & $0.97^{* *}$ & $1.00^{* *}$ & $0.92^{*}$ & 1 & & & & & \\
Cltd & $0.97^{* *}$ & $1.00^{* *}$ & $0.92^{*}$ & $1.00^{* *}$ & 1 & & & & \\
Cltd/Car & $0.88^{*}$ & $0.95^{* *}$ & $0.85^{*}$ & $0.94^{* *}$ & $0.95^{* *}$ & 1 & & & \\
Gcla & $0.98^{* *}$ & $0.93^{* *}$ & $0.87^{*}$ & $0.94^{* *}$ & $0.93^{* *}$ & $0.86^{*}$ & 1 & & \\
Gclb & $0.97^{* *}$ & $0.96^{* *}$ & $0.87^{*}$ & $0.96^{* *}$ & $0.96^{* *}$ & $0.93^{* *}$ & $0.99^{* *}$ & 1 & \\
Gclt & $0.98^{* *}$ & $0.94^{* *}$ & $0.87^{*}$ & $0.95^{* *}$ & $0.95^{* *}$ & $0.90^{*}$ & $1.00^{* *}$ & $1.00^{* *}$ & 1 \\
\hline
\end{tabular}

**, * Significant at $\mathrm{p}<0.01$ and $\mathrm{p}<0.05$, respectively, by the T test. GY: grain yield; Clad, Clbd and Cltd: contents of chlorophyll $a, b$ and total, respectively; Car and Cltd/Car: carotenoids and ratio between total chlorophyll and carotenoids, respectively, extracted by DMSO methods; Gcla, Gclb and Gclt: chlorophyll $a, b$ and total, respectively, determined in the field by the chlorophyll method. 


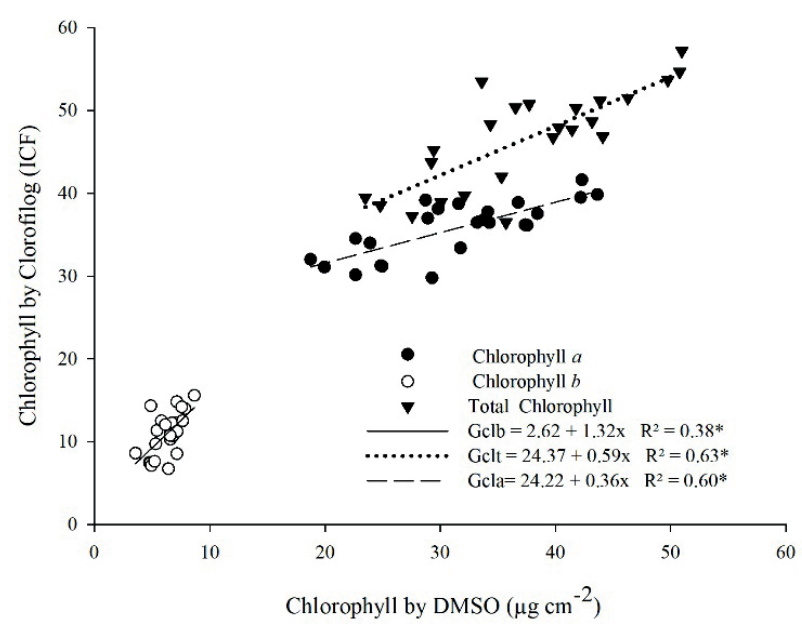

Figure 4. Linear regression analysis of chlorophylls $a, b$ and total, determined by the DMSO laboratory destructive method and the field estimation method via CLOROFILOG ${ }^{\mathrm{TM}}$. * Significant at $5 \%$ of probability.

chlorophyll method as an alternative tool for field evaluation, promoting greater savings in resources and greater speed of diagnosis of the photosynthetic capacity of the analyzed plants.

For Ya-wei et al. (2019), corn hybrids that have a higher chlorophyll content perform more photosynthesis, with a better development; and plants subjected to low $\mathrm{N}$ fertilization have a greater ability to intercept light, but the ability to absorb and transmit is impaired, inhibiting photosynthesis. The high correlation between carotenoids and grain yield may be justified by the involvement in the photosynthesis process, either as an accessory antenna to absorb light or as an antioxidant agent (Pérez et al. 2012). Another important point to observe is the correlation between carotenoids and N. Santos et al. (2019) showed high correlations, when studying photosynthetic pigments and leaf $\mathrm{N}$ in Bermuda grass.

The high correlation between the chlorophyll contents and grain yield allows the use of the field chlorophyll meter as a parameter to evaluate the crop and estimate grain yield, because the photosynthesis, that is crucial for the energy production of the plant and result in grain production, is dependent on the presence of chlorophylls and carotenoids, which have a strong relationship with the presence of $\mathrm{N}$ in the plant (França et al. 2011). However, this result differs from Quadros et al. (2014), who found no correlation between chlorophyll content and corn grain yield of three corn hybrids inoculated with three mixtures of A. brasilense.
Morais et al. (2015) observed that the chlorophyll content has a high correlation with corn grain yield. However, this is evidenced in more advanced stages, when the productive potential of the plant has already been defined and no nitrogen management can be carried out. This information may be used to base growth and production estimation models for harvest planning and identification of areas that need some different management in future crops.

\section{CONCLUSIONS}

1. There was a positive relationship between the methods for determining and estimating the chlorophyll levels in corn plants, even when submitted to different nitrogen sources;

2. The grain yield per plant showed the highest values when the fertilization source was $100 \%$ mineral, followed by the association of the sources and finally the treatments without fertilization and with inoculation. The shoot dry biomass yield was not influenced by the different $\mathrm{N}$ sources;

3. There was a positive correlation between the photosynthetic pigments determined and estimated by both methods and the grain yield per plant, showing a strong relationship and importance for plant production;

4. Both methods are recommended for the evaluation of chlorophyll in corn plants. In addition, the use of mineral nitrogen sources offers a better response to grain yield.

\section{REFERENCES}

ALVARES, C. A.; STAPE, J. L.; SENTELHAS, P. C.; GONÇALVES, J. L. de M.; SPAROVEK, G. Köppen's climate classification map for Brazil. Meteorologische Zeitschrift, v. 22, n. 6, p. 711-728, 2013.

CRUZ, C. D. Genes: a software package for analysis in experimental statistics and quantitative genetics. Acta Scientiarum Agronomy, v. 35, n. 3, p. 271-276, 2013.

DARTORA, J.; GUIMARÃES, F. V.; MARINI, D.; SANDER, G. Adubação nitrogenada associada à inoculação com Azospirillum brasilense e Herbaspirillum seropedicae na cultura do milho. Revista Brasileira de Engenharia Agrícola e Ambiental, v. 17, n. 10, p. 10231029, 2013.

EMPRESA BRASILEIRA DE PESQUISA AGROPECUÁRIA (Embrapa). Centro Nacional de 
Pesquisa de Solos. Sistema brasileiro de classificação de solos. Brasília, DF: Embrapa, 2018.

FERRO, A. E. M. M.; BORSOI, A.; SOUZA, L. C. de; ROSSET, J. S. Atributos agronômicos da cultura do trigo sob diferentes fontes de adubação. Acta Iguazu, v. 7, n. 3, p. 50-59, 2018.

FRANÇA, S.; MIELNICZUK, J.; ROSA, L. M. G.; BERGAMASCHI, H.; BERGONCI, J. I. Nitrogênio disponível ao milho: crescimento, absorção e rendimento de grãos. Revista Brasileira de Engenharia Agrícola e Ambiental, v. 15, n. 11, p. 1143-1151, 2011.

GONÇALVES JÚNIOR, A. C. G.; NERES, M. A. Substituição da adubação nitrogenada mineral pela cama de frango na sucessão aveia/milho. Bioscience Journal, v. 30, n. 3, p. 272-281, 2014.

HARTY, M. A.; FORRESTAL, P. J.; CAROLAN, R.; WATSON, C. J.; HENNESSY, D.; LANIGAN, G. J.; WALL, D. P.; RICHARDS, K. G. Temperate grassland yields and nitrogen uptake are influenced by fertilizer $\mathrm{N}$ source. Agronomy Journal, v. 109, n. 1, p. 1-9, 2017.

HURTADO, S. M. C.; RESENDE, A. V.; SILVA, C. A.; CORAZZA, E. J.; SHIRATSUCHI, L. S. Clorofilômetro no ajuste da adubação nitrogenada em cobertura para o milho de alta produtividade. Ciência Rural, v. 41, n. 6, p. 1011-1017, 2011.

HURTADO, S. M. C.; SILVA, C. A.; RESENDE, Á. V.; CORAZZA, E. J.; SHIRATSUCHI, L. S.; HIGASHIKAWA, F. S. Sensibilidade do clorofilômetro para diagnóstico nutricional de nitrogênio no milho. Ciência e Agrotecnologia, v. 34, n. 3, p. 688-697, 2010.

KAPPES, C.; ARF, O.; ARF, M. V.; FERREIRA, J. P.; DAL BEM, E. A; PORTUGAL, J. R.; GONÇALVES, R. $\mathrm{V}$. Inoculação de sementes com bactéria diazotrófica e aplicação de nitrogênio em cobertura e foliar em milho. Semina: Ciências Agrárias, v. 34, n. 2, p. 527-538, 2013.

LANA, M. do C.; DARTORA, J.; MARINI, D.; HANN, J. E. Inoculation with Azospirillum, associated with nitrogen fertilization in maize. Revista Ceres, v. 59, n. 3, p. 399405, 2012.

LATSAGUE, M.; SAEZ, P.; MORA, M. Efecto de la fertilización con nitrógeno, fósforo y potasio, sobre el contenido foliar de carbohidratos, proteínas y pigmentos fotosintéticos en plantas de Berberidopsis corallina Hook. f. Gayana Botanica, v. 71, n. 1, p. 37-42, 2014.

MARTÍNEZ, E.; DOMINGO, F.; ROSELLÓ, A.; SERRA, J.; BOIXADERA, J.; LLOVERAS, J. The effects of dairy cattle manure and mineral $\mathrm{N}$ fertilizer on irrigated maize and soil $\mathrm{N}$ and organic C. European Journal of Agronomy, v. 83 , n. 1, p. 78-85, 2017.
MINOGUE, P. J.; OSIECKA, A.; MACKOWIAK, C.; NOWAK, J. Leaching potential with diammonium phosphate and poultry litter fertilization of young pine plantations in the Florida sandhills. Southern Journal of Applied Forestry, v. 36, n. 4, p. 181-190, 2012.

MORAIS, T. P. de; BRITO, C. H. de; FERREIRA, A. de S.; LUZ, J. M. Q. Aspectos morfofisiológicos de plantas de milho e bioquímico do solo em resposta à adubação nitrogenada e à inoculação com Azospirillum brasilense. Revista Ceres, v. 62, n. 6, p. 589-596, 2015.

PÉREZ, V. S.; MERINO, F. C. G.; ZAVALA, J. J. G.; FERREIRA, J. B.; VARELA, A. S.; ROJAS, N. P.; TIESSEN, A. QTLs asociados al contenido de carotenos en hojas de maíz (Zea mays L.). Agrociencia, v. 46, n. 4, p. 333-345, 2012.

PORTUGAL, J. R.; ARF, O.; PERES, A. R.; GITTI, D. C.; GARCIA, N. F. S. Coberturas vegetais, doses de nitrogênio e inoculação com Azospirillum brasilense em milho no Cerrado. Revista Ciência Agronômica, v. 48, n. 4, p. 639-649, 2017.

PRAKAMHANG，J.; MINAMISAWA，K.; TEAMTAISONG, K.; BOONKERD, N.; TEAUMROONG, $\mathrm{N}$. The communities of endophytic diazotrophic bacteria in cultivated rice (Oryza sativa L.). Applied Soil Ecology, v. 42, n. 2, p. 141-149, 2009.

QUADROS, P. D. de; ROESCH, L. F. W.; SILVA, P. R. F. da; VIEIRA, V. M.; ROEHRS, D. D.; CAMARGO, F. A. de O. Desempenho agronômico a campo de híbridos de milho inoculados com Azospirillum. Revista Ceres, v. 61, n. 2, p. 209-218, 2014.

SÁNCHEZ, E.; RUIZ, J. M.; ROMERO, L.; RANGEL, P. P.; CÓRDOVA, M. A. F.; QUIROZ, C. M. ¿Son los pigmentos fotosintéticos buenos indicadores de la relación del nitrógeno, fósforo y potasio en frijol e jotero? Ecosistemas y Recursos Agropecuarios, v. 5, n. 15, p. 387 398, 2018.

SANGOI, L.; SILVA, L. M. M.; MOTA, M. R.; PANISON, F.; SCHMITT, A.; SOUZA, N. M.; GIORDANI, W.; SCHENATTO, D. E. Desempenho agronômico do milho em razão do tratamento de sementes com Azospirillum sp. e da aplicação de doses de nitrogênio mineral. Revista Brasileira de Ciência do Solo, v. 39, n. 4, p. 1141-1150, 2015.

SANTOS, L. B.; CASTAGNARA, D. D.; BULEGON, L. G.; ZOZ, T.; OLIVEIRA, P. S. R.; SANTOS, P. L. F. dos; CASTILHO, R. M. M. de; GAZOLA, R. P. D. Pigmentos fotossintéticos e sua correlação com nitrogênio e magnésio foliar em grama Bermuda cultivada em substratos. Acta Iguazu, v. 8, n. 1, p. 92-101, 2019. 
SANTOS, R. P.; CRUZ, A. C. F. da; IAREMA, L.; KUKI, K. N.; OTONI, W. C. Protocolo para extração de pigmentos foliares em porta-enxertos de videira micropropagados. Revista Ceres, v. 55, n. 4, p. 356-364, 2008.

SCHLICHTING, A. F.; BONFIM-SILVA, E. M.; SILVA, M. de C.; PIETRO-SOUZA, W.; SILVA, T. J. A. da; FARIAS, L. N. Efficiency of portable chlorophyll meters in assessing the nutritional status of wheat plants. Revista Brasileira de Engenharia Agrícola e Ambiental, v. 19, n. 12, p. 1148-1151, 2015.

SOCIEDADE BRASILEIRA DE CIÊNCIA DO SOLO (SBCS). Comissão de Química e Fertilidade do Solo CQFS-RS/SC. Manual de calagem e adubação para os estados do Rio Grande do Sul e Santa Catarina. 11. ed.
Porto Alegre: Sociedade Brasileira de Ciência do Solo; Comissão de Química e Fertilidade do Solo - RS/SC, 2016.

WELLBURN, A. R. The spectral determination of chlorophylls $a$ and $b$, as well as total carotenoids, using various solvents with spectrophotometers of different resolution. Journal of Plant Physiology, v. 144, n. 3, p. 307-313, 1994.

YA-WEI, W.; QIANG, L.; RONG, J.; WEI, C.; XIAO-LIN, L.; FAN-LEI, K.; YONG-PEI, K.; HAICHUN, S.; JI-CHAO, Y. Effect of low-nitrogen stress on photosynthesis and chlorophyll fluorescence characteristics of maize cultivars with different low nitrogen tolerances. Journal of Integrative Agriculture, v. 18 , n. 6 , p. 1246-1256, 2019. 